\section{Cannabis legal debacle}

To the Editor: The editorial in the SAMJ ${ }^{1}$ questioning whether it is time to decriminalise drugs refers.

The Central Drug Authority (CDA) produced the South African Position Paper on Cannabis in 2004; however, the document was never made public or released. ${ }^{2}$ The Position Paper builds a case for prohibition on a 'public health' basis and ostensibly represents the government's position regarding cannabis.

The Position Paper is fatally flawed, particularly considering that it does not contain a discussion regarding the numbers of deaths from the drug. The 2002 Canadian Senate investigation into cannabis reported that 'Cannabis presents almost no toxicity and cannot lead to an overdose. 3 The authors of the Position Paper found it possible to ignore this finding, incredibly excluding any discussion of mortality from the entire paper. If the Canadians are correct, and if smoking cannabis is essentially harmless - since there are no bodies to point to - why does the state constantly arrest and lock people up for it? South Africa has 3195000 cannabis users $^{4}$ yet the CDA failed to produce one body as evidence of its danger.

The Position Paper furthermore does not examine the costs or the consequences of the prohibition it perpetuates. It makes no mention of the number of arrests for cannabis and the consequences of subsequent prosecutions and incarceration. In 2008/9, the SA Police Services (SAPS) arrested 111548 people for drug-related matters. Cannabis accounts for over $80 \%$ of drug investigations by SAPS, ${ }^{5}$ which means that around 90000 people were arrested for cannabis possession, cultivation and sale. The SAPS use helicopters to spray large cannabis plantations with glyphosate. The areas sprayed for the years 2006 - 2009 were 170 hectares, 260 hectares, 1745 hectares and 1275 hectares respectively. The Position Paper is silent on spraying and its potential health effects. The Canadian Senate investigation found that the cost of policing the prohibition constitutes the predominant cost of the prohibition. ${ }^{6}$

The history of the prohibition of cannabis in South Africa reveals an inherently racist foundation for prohibition. This consideration is not mentioned in the Position Paper - and neither is South Africa's leading role in having cannabis prohibited internationally in 1923.

Notwithstanding the call made in the 1999 National Drug Master Plan for research into decriminalisation and legalisation of cannabis, there is no discussion of a possible change in the legal position in the Position Paper.

The prohibition has failed. The Position Paper is government propaganda filled with half-truths and misrepresentations. The time has come to question the efficacy of treating drug addiction through legal wranglings and incarceration - rather than treating it as the medical problem it is.

\section{Marius de Kock}

Attorney

Cape Town

ilollipop2@gmail.com

1. Van Niekerk JPdeV. Time to decriminalise drugs? S Afr Med J 2011;101(2): 84-85

2. http://www.wikileaks.ch/wiki/South_Africa_Central_Drug_Authority_Position_Paper_on_ Cannabis,_2004 (accessed 15 March 2011).

Report of the Senate Special Committee on Illegal Drugs, September 2002. Ottowa: Parliament of Report of the Senate Special Committee on Illegal Drugs, September 2002. Ottowa: Parliament of
Canada, 2002:6. http://www.parl.gc.ca/37/1/parlbus/commbus/senate/com-e/ille-e/rep-e/summary-e. htm (accessed 15 March 2011 .

4. Central Drug Authority Annual Report 2008/9. Pretoria: Central Drug Authority, 2009:137.

5. Central Drug Authority Annual Report 2008/9. Pretoria: Central Drug Authority, 2009:80.

6. Report of the Senate Special Committee on Illegal Drugs, September 2002. Ottowa: Parliament of Canada, 2002:28. http://www.parl.gc.ca/37/1/parlbus/commbus/senate/com-e/ille-e/rep-e/summary-e. htm (accessed 15 March 2011).

\section{Decriminalisation of drugs}

To the Editor: I appreciated the editorial ${ }^{1}$ on the decriminalisation of drugs, which argued that psychoactive drugs are part of human antiquity, that world-wide attempts to 'clean up' the drug scene have been counterproductive, that the 'war' on drugs has failed, and that attempts to root out drug barons and supply routes has hiked prices and destabilised political systems rather than achieving the noble aim of drug eradication. With subtle reference to human hypocrisy, Professor Van Niekerk points out that official acknowledgement of the futility of drug wars is political suicide. He makes the sobering observation that tobacco and alcohol are in the top half of the ranking scale of human harm and yet these drugs are legal. He implies that decriminalising the others will go a long way toward relinquishing the lucrative control of drug dealing from the barons to the State, which could put the money to better use.

This is food for thought and, hopefully, to civilised debate. Any quick legislative response to Van Niekerk's pragmatic suggestions is unlikely. Instead, in the light of the drug trafficking process (manufacturer - dealer - user) I suggest that the first step towards the decriminalisation of drugs be a focus not on the drugs but on those who take them. I agree with Van Niekerk's statement that 'making people criminals for taking psychoactive substances is in itself criminal for one is dealing with a vice and not a crime. This drug use and abuse - be it tobacco, alcohol, marijuana or the refined 'speedline' drugs - is not going to go away. The exploratory or seeking drive - be it for food, water, reward, stress release or meaning - is hard-wired into humans. Risk taking, innovation and opportunism (among others) are also essential survival strategies. Humans are a creative and social species. Kinship recognition and a sense of belonging are key ingredients in holding societies together. Enter the many and varied rituals and rites of passage-defining in-groups and out-groups, and it is clear that the dynamics of individual drug taking and drug abuse are biologically, socially and psychologically complex.

Despite peer pressure, conformity and that sometimes deep narcissistic need to belong, the majority of human beings somehow succeed in finding that illusive balance between individual needs, thrills, expectations of others, personal insight and socialisation. Some get it wrong and, with that comes the collapse of the triad of requirements necessary for social and individual well-being - a creative sense of self, creative relationships and a meaningful job or career. The frustration, anger and heartache that comes with this collapse distresses us and spurs our search for solutions, one of which is to criminalise the offender. I agree that this has to change, and that it is not about condoning the use and abuse of any particular form of drug, but about understanding the shame, isolation and hopelessness experienced by individuals who are perceived as social failures as well as criminals. Think of the impact of such a criminal label on possible rehabilitation. To me, it is worth noting that, long after the early experimentation with drugs and with it the 'highs' and 'lows' of substance abuse, addicts, once addicted, continue taking drugs not for the 'high' but to feel 'normal'.

Should drug taking become a non-criminal offence, would this translate into an open invitation to 'party'? I doubt it. We are going to 'party' anyway. I choose instead not to underestimate the intelligence and capacity of most human beings to decide for themselves. Rather than exacerbating the problem by decriminalising possession of drugs, I think the reverse will happen. We all know that 'stolen fruit' tastes better than the legal variety, not because of the taste but because of the challenge of succeeding and getting away with it. Despite the 